This document is the accepted manuscript version of the following article:

Hossu, C. A., Ioja, I. C., Nita, M. R., Harte1, T., Badiu, D. L., \& Hersperger, A. M. (2017). Need for a cross-sector approach in protected area management. Land Use Policy, 69, $586-597$. https://doi.org/10.1016/j.1andusepo1.2017.10.012

This manuscript version is made available under the CC-BY-NC-ND 4.0

license http://creativecommons.org/1icenses/by-nc-nd/4.0/

\title{
Need for a cross-sector approach in protected area management
}

Constantina Alina Hossu ${ }^{1}$, Ioan Cristian Ioja ${ }^{1 *}$, Mihai R. Nita ${ }^{1}$, Tibor Hartel ${ }^{2}$, Denisa L. Badiu ${ }^{1}$, Anna M. Hersperger ${ }^{3}$

${ }^{1}$ Centre for Environmental Research and Impact Studies, University of Bucharest, Nicolae Balcescu 1, 010041 Bucharest, Romania

${ }^{2}$ Ecosystem Services Laboratory, Sapientia Hungarian University of Transylvania, Matei Corvin 4, 400112 Cluj-Napoca, Romania

${ }^{3}$ Swiss Federal Research Institute of Forest, Snow and Landscape, Landscape Dynamics, Zürcherstrasse 11, 8903 Birmensdorf, Switzerland

Submitted to: Land Use Policy

The need for various stakeholders to harmonize their policies and practices has emerged as a

3 dominant paradigm for $21^{\text {st }}$ century natural resource management. Cross-sector coordination is

4 promising because it can enhance policy consistency, enable the realization of synergies and

5 resolve conflicts among sectors regarding resource management. The extent to which ministries

6 and their main stakeholders make efforts to achieve integrated policies for nature conservation

7 requires further research. Therefore, the aim of this study was to explore the consultation reports

8 of ministries from relevant fields (i.e., environmental protection, agriculture, spatial planning,

9 and security) regarding the management plans for Romania's protected areas. We analysed and

10 visualized 152 consultation reports (2013-2016) covering 15\% of Romania's protected areas

11 using self-organizing maps (SOMs), an unsupervised machine-learning method. Our results 
12 showed that considerable attention was paid to formal issues in these reports. The cross-sector

13 issues that emerged as the most important were those related to forest landowner consultation,

14 and the harmonization of agricultural and forestry practices, as well as spatial plans for

15 conservation. The resulting SOMs could be used as a tool to strengthen protected area

16 management in the future because they can (i) guide managers of protected areas to develop

17 plans that ensure that resources will be used in the best way according to the visions of multiple

18 sectors and (ii) help the relevant ministries to improve future consultation reports.

19

20 Keywords: consultation; nature conservation; protected area; self-organizing map; Romania 


\section{Introduction}

The changing views on nature and conservation (Mace, 2014) as well the complex and uncertain problems in resources management made the central governments to adhere to decentralized conservation decision making (Berkes, 2010). Continuous efforts are made at the EU level to move toward a participatory approach (i.e., through Public Participation Directive (2003/35/EC); Public Access to Information on the Environment Directive (2003/4/EC), Environmental Assessment Directives (2011/92/EU and 2001/42/EC); and Water Framework states ensure stakeholders' consultation and encourage participation in order to enhance the legitimacy of decision making.

Directive (2000/60/EC)). According to these directives it is highly recommended that member

Public participation ranges from state actors' consultation toward more citizens involvement issues (Newig and Fritsch, 2009a), the non-state actors may provide valuable local knowledge that can complement expert knowledge (Reed et al., 2007). In practice, public participation has proved effective in increasing the quality of plans and their legitimacy (Burby, 2003; Newig et al., 2016), achieving more inclusive conservation solutions (Whitehead et al., 2014) and driving positive changes in biodiversity conservation (Hill et al., 2015). However, resource management plans are often abstract, lack detail and present vague indications about the implementation of measures. This is especially the case if they are only developed to meet the European Commission requirements (Newig et al., 2016).

Protected areas are among the most effective institutional arrangements for safeguarding biodiversity (Possingham et al., 2007) and ensuring the well-being of a community (Thapa Karki, 2013). They have achieved significant prominence in many countries around the world 
44 (Joppa et al., 2016). The Natura 2000 network is the most extensive protected area system in

45 European Union (EU), and covers approximately $18 \%$ of the EU territory (EC, 2016).

Government-controlled protected areas for which the responsibility lies with public

47 authorities represent one of the most common forms of management (Borrini-Feyerabend and Hill, 2015). A key condition for a socially and ecologically acceptable management of protected areas is related to the capacity and willingness of the various stakeholders to collaborate for nature conservation (Avdibegović et al., 2015). This is a challenging task, especially because the

51 economic sectors related to natural resource management (i.e., agriculture, forestry) and spatial

52 planning either (i) have no experience in protected area management and 'conservation thinking'

53 and/or (ii) exploit natural resources, which often conflicts with conservation. Indeed policies on

54 key economic sectors are primarily concerned with optimization of production and sectoral 55 policy mandates are often conflicting (Roux et al., 2008).

56 Cross-sector coordination is thus important. It can ensure that the same concepts and thinking 57 are used in all sectors which enhances policy consistency (Stringer et al., 2014) and that 58 synergies across different sectors can be realized (Roux et al., 2008). When issues (such as

59 protected areas management) are of cross-sector importance, stakeholders from different sectors

60 should engage in dialogue to formulate common goals as well as clarify and resolve

61 disagreements through negotiation and consensus building (Innes and Booher, 2003). This can

62 facilitate knowledge exchange which in turn can lead to innovative policy outputs. Even though 63 mainstreaming of conservation in sectoral strategies is increasingly common (EC, 2012), it does 64 so far not deliver the expected benefits of cross-sector coordination since conservation continues 65 to receive little weight compared with other policy sectors (Spierenburg, 2012). 
Management plans are key instruments by which managers of protected areas promote

67 conservation activities. For ministerial acceptance of the management plans in Romania, consultation with various relevant stakeholders is mandatory (Figure 1). These stakeholders are typically asked to review the content of the management plans and to propose modifications for various issues they consider relevant.

In Romania, as in most other countries, inter-ministerial consultation is common in both the activities to be regulated (Staronova and Mathernova, 2003), develops mutually agreed management measures across different sectors (Olsen et al., 2014) and prevents resource conflicts (Schilling-Vacaflor, 2014).

The resulting consultation reports are documents that consist of comments and observations regarding the substantive aspects of each stakeholder's policy (Matei and Dogaru, 2013).

Specifically, in the consultation reports of protected area management plans, ministries, local public authorities or NGOs make requests (i.e., modifying conservation activities to best manage a protected area, recommending the consideration of additional threats that may affect a protected area, or harmonizing legislation). At the EU level, there is no obligation for stakeholders' involvement in the development of protected area management plans (Unnerstall, 2008) and no obligation for the managers of the protected areas to revise plans according to stakeholders' requests. In Romania, the Government Decision. no. 561/2009 (GD No 561, 2009) creates the opportunity for stakeholders to comment on draft management plans. The resulting requests are considered by the managers of the protected areas but without any obligation to address them in the plan. This procedure is common in other countries such as the Netherlands and Germany (Unnerstall, 2008). In fact, Newig et al., (2016) found in their analysis of 
Germany's implementation of the EU Water Framework Directive that the written feedback from

90 participatory processes was often not included in the final plans (Koontz and Newig, 2014).

In Romania, the experts write the consultation reports with the goal of providing feedback in line with the policies governed by the institutions they represent to harmonize their policies with nature conservation policies. These experts are instructed to note the incompatibilities between the management plans and policy, to suggest solutions to strengthen biodiversity conservation using arguments specific to their interests, as well as to note contradictions with existing legislation.

Because Romania has a high proportion of protected areas which is growing every year (Ioja et al., 2010), solid knowledge about their management is a top priority. Romania is a particularly appropriate country in which to conduct this study for the following reasons. First, Romania is extremely rich in genuine cultural landscapes that support a high level of biodiversity (Sutcliffe et al., 2015). Some of these landscapes are veritable 'biocultural refuges' due to high biodiversity, local ecological knowledge and skills related to nature resource management (Barthel et al., 2013). Second, the socio-economic goals of the inhabitants of these landscapes are strongly oriented towards western ideals, while most ecosystem services and biological legacies are less of a priority (Hartel et al., 2014). This, together with the scarce government revenue increases conflicts related to resource management (Ioja et al., 2010). As is commonly the case across contexts, nature conservation is perceived as barrier to economic development (Newig and Fritsch, 2009b). However, when nature conservation supports economic well-being, it gains support from local communities (Newig and Fritsch, 2009b). Third, cross-sector cooperation is scarce in Romania (Nita et al., 2016) which may hamper the good governance of protected areas (Lockwood, 2010). Fourth, since its entry into the EU (2007) Romania has had 
112 the obligation to delineate Natura 2000 protected areas and to fund their conservation

113 management (Ioja et al., 2010) which requires supporting research.

114 The aim of this study is to explore the content of the consultation reports in order to assess

115 the extent to which they focus on cross-sector issues. We expect these consultation reports

116 placed a substantial emphasis on cross-sector issues by either describing how each ministry's

117 interests interfered with nature conservation or by addressing procedural issues of cross-sector

118 harmonization as protected areas serve multiple goals and encompass multiple resources with

119 overlapping management responsibilities (Apostolopoulou and Pantis, 2009). These multiple

120 goals are often conflicting (Hersperger et al., 2015; Tudor et al., 2014) and management plans

121 are created to coordinate such conflicts (Young et al., 2015).

122 In the context of our paper, interfering interests take place when a ministry's interest is

123 affected by conservation actions. For example, the request in the management plan to manage a

124 forest located in a protected area for high biodiversity or for certain red-listed species interferes

125 with the interest of the ministry of forestry.

126 The issue of cross-sector harmonization refers to harmonizing among existing practices and

127 legislation in the ministries and the newly developed management plans.

128 Self-organizing maps (SOMs), a method that performs content-based organization of

129 consultation reports was used to reveal the general and most frequent requests made by the

130 selected stakeholders regarding the management plans for Romania's protected areas.

132 2. Methods

$133 \quad$ 2.1.Study area 
Romania's protected area network includes 608 Natura 2000 protected areas (437 Sites of

135 Community Importance - SCIs and 171 Special Protection Areas - SPAs), 29 natural and national

136 parks and over 900 other protected areas such as natural reserves or natural monuments that occupy

137 more than $23 \%$ of the country's area (EC, 2016). Most protected areas have their own

138 administrations (or custodians) and the larger ones have a Scientific Council and an Advisory

139 Council which deals with complex issues. These councils include both state and local stakeholders

140 with a stake in protected area management. The Ministry of the environment delegates the

141 management to other stakeholders, via competition, such as agencies in the ministry, NGOs, local

142 governmental authorities, or even private parties (Borrini-Feyerabend and Hill, 2015).

143 The conservation activities in protected areas are established through management plans.

144 Management plans for protected areas are required to engage multiple stakeholders in the

145 development process and address potential threats to a protected area as well as the action taken

146 to improve conservation (Szabo et al., 2008). More than 15 years after the revalidation of the

147 national protected area network (Law no. 5/2000 - the legal basis for declaring a protected area)

148 and almost 10 years after the establishment of the first protected areas in the Natura 2000

149 network, the development of management plans is still ongoing. In fact, only $43 \%$ of protected

150 areas have an approved management plan today (Romanian Government, 2015). This is partly

151 because limited financial resources for conservation and lack of financial incentives to cover

152 immense costs related to compensation (Ioja et al., 2010) as well as the newly established Natura

1532000 sites which do not have yet a management agency (Ministry of the Environment, 2016) or

154 the agency did not have yet the time to develop a management plan.

155 Management plans are developed by the protected area manager and have to be officially 156 approved by the ministry of the environment. This study considers the last step preceding official 
approval and specifically addresses the inter-institutional consultation (Figure 1). At this stage, the ministry of the environment first evaluates a plan by itself or hires experts to perform the evaluations according to a specific process. The plans are then sent back to the protected area manager for revision. Before a plan is finally approved by the ministry of the environment, it is sent to other ministries who provide written feedback (i.e., inter-institutional consultation).

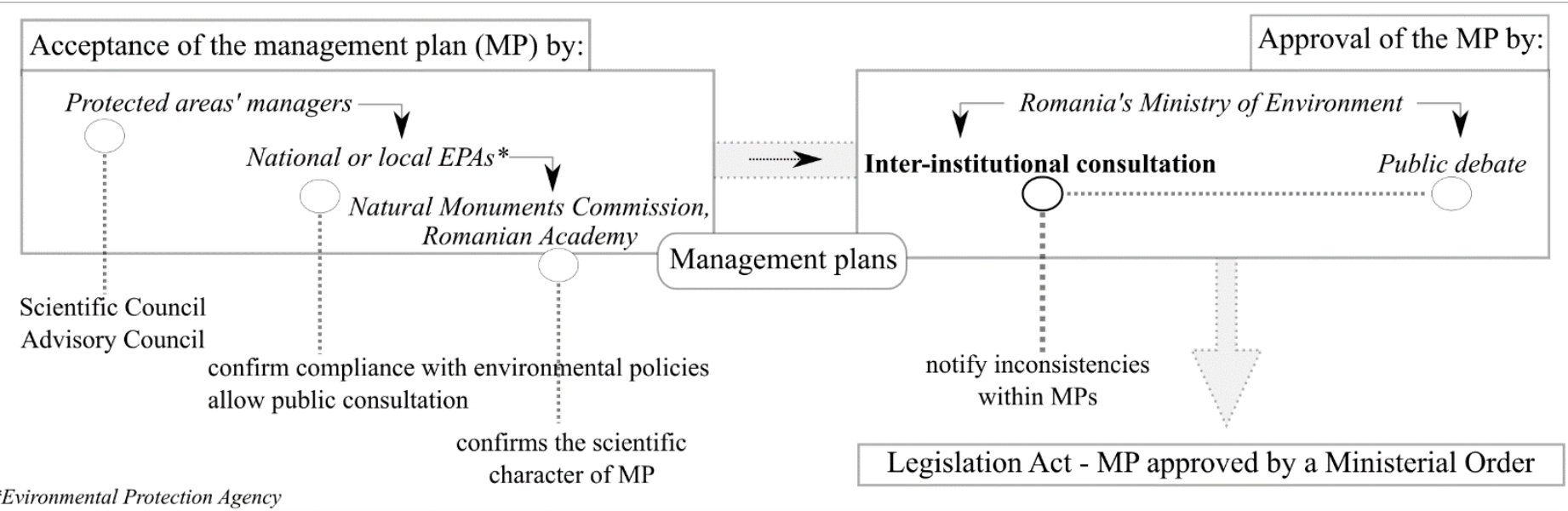

*Evironmental Protection Agency

Figure 1: Steps in the approval of a protected area management plan

In the context of our paper, ministries are conceptualized as institutions, following the definition of Ostrom (1990), since they embody a set of rules, public norms, practices, policies or other outcomes. Furthermore, the experts that write the consultation reports and represent a ministry can be defined as organizations, following the definition of North (1990), since they are a group of actors having the common goal to comment on the protected areas management plans.

\subsection{Dataset}

Consultation reports by the ministries in the fields of environmental protection, agriculture, spatial planning, and security were used as input data for our analysis (Table 1) ${ }^{1}$. The interests of these ministries are closely linked to protected area management. The ministry of environmental

\footnotetext{
${ }^{1}$ We refer broadly to the ministry's field since the names of the ministries have repeatedly changed in the past.
} 
173 protection is responsible for coordinating policies across several domains, such as biodiversity,

174 forest and water management, climate change, etc. It sees protected areas as spaces which can

175 contribute to the achievement of environmental goals and counter-balance the negative effects of

176 social and economic development. The ministry of agriculture aims at the sustainable

177 development of agricultural activities, including the sustainable use of resources. In terms of

178 spatial planning, protected areas are often perceived as spaces useful for balancing the economic

179 and demographic pressures of other areas. The ministry of security is responsible for protecting

180 the country's natural resources and ensuring access to recreational and leisure areas (including

181 different types of protected areas).

182 This paper assessed 152 consultation reports (2013-2016) concerning management plans of

18391 of Romanian protected areas (15\% of the total number of protected areas) (Table 1). The

184 number of the consultation reports is higher than the number of protected areas because (i) when

185 a consultation report contained requests on both a management plan and a regulation (a separate

186 section of the management plan, which consists of a set of rules regarding permitted or restricted

187 human activity in a protected area) we considered it as two separate reports, one referring to the

188 management plan and one referring to the regulation and (ii) some consultation reports were

189 general, i.e., done for a group of protected areas. These general reports were not assigned to a

190 specific protected area.

191 Some consultation reports were short, often less than one page, while others were 4-5

192 pages. Many protected areas received reports on their management plans from one ministry,

193 while other got reports from two or three ministries.

$194 \quad$ Table 1: Ministries involved in the consultation reports of protected areas (PAs)

195 management plans (MPs); Number of consultation reports and protected areas 


\begin{tabular}{|c|c|c|c|c|}
\hline Ministries & $\begin{array}{l}\text { Ministry of the } \\
\text { environment, Waters and } \\
\text { Forests }\end{array}$ & $\begin{array}{l}\text { Ministry of } \\
\text { Agriculture and Rural } \\
\text { Development }\end{array}$ & $\begin{array}{l}\text { Ministry of Regional } \\
\text { Development and } \\
\text { Public Administration }\end{array}$ & $\begin{array}{l}\text { Ministry of } \\
\text { Internal Affairs }\end{array}$ \\
\hline Main area & Environmental Protection & Agriculture & Spatial planning & Security \\
\hline $\begin{array}{l}\text { Common interests } \\
\text { with natural } \\
\text { resources managers }\end{array}$ & $\begin{array}{l}\text { Biodiversity conservation; } \\
\text { Control of environmental } \\
\text { degradation sources }\end{array}$ & Soil conservation & $\begin{array}{l}\text { Natural resource } \\
\text { conservation }\end{array}$ & $\begin{array}{l}\text { Complying with } \\
\text { rules on natural } \\
\text { resources } \\
\text { exploitation }\end{array}$ \\
\hline $\begin{array}{l}\text { Conflicting interests } \\
\text { with natural } \\
\text { resources managers }\end{array}$ & $\begin{array}{l}\text { Forestry; Water } \\
\text { management }\end{array}$ & $\begin{array}{l}\text { Agricultural activities } \\
\text { (including subsidies) }\end{array}$ & $\begin{array}{l}\text { Urbanization; } \\
\text { Infrastructure } \\
\text { development }\end{array}$ & $\begin{array}{l}\text { Management of the } \\
\text { areas relevant for } \\
\text { national security }\end{array}$ \\
\hline $\begin{array}{l}\text { Measures for } \\
\text { reducing conflicting } \\
\text { interests }\end{array}$ & $\begin{array}{l}\text { Sustainable forestry; } \\
\text { Environmental Impact } \\
\text { Assessment; Sustainable } \\
\text { Water Management }\end{array}$ & Ecological farming & $\begin{array}{l}\text { Sustainable spatial } \\
\text { planning; eco-buildings; } \\
\text { green infrastructure }\end{array}$ & \\
\hline $\begin{array}{l}\text { Coordinated } \\
\text { strategies }\end{array}$ & $\begin{array}{l}\text { Strategy for Sustainable } \\
\text { Development; Strategy for } \\
\text { Biodiversity Conservation; } \\
\text { Strategy for climate change } \\
\text { mitigation; National } \\
\text { Strategy for Forest } \\
\text { Management }\end{array}$ & $\begin{array}{l}\text { Fisheries National } \\
\text { Strategic Plan; National } \\
\text { Strategy for Rural } \\
\text { Development }\end{array}$ & $\begin{array}{l}\text { National Spatial Plan, } \\
\text { Strategy for Territorial } \\
\text { Development }\end{array}$ & $\begin{array}{l}\text { National Strategy } \\
\text { for Security, Public } \\
\text { Administration Law }\end{array}$ \\
\hline $\begin{array}{l}\text { Consultation reports } \\
\text { (Total - no.) }\end{array}$ & $\begin{array}{l}47 \text { (from which } 39 \text { are on } \\
\text { individual MPs assigned to } \\
\text { a different PA; } 6 \text { are general } \\
\text { on a group of MPs assigned } \\
\text { to a group of PAs, } 2 \text { are on } \\
\text { a regulation of a PA) }\end{array}$ & $\begin{array}{l}66 \text { (from which } 46 \text { are } \\
\text { on individual MPs } \\
\text { assigned to a different } \\
\text { PA; } 4 \text { are general on a } \\
\text { group of MPs assigned } \\
\text { to a group of PAs, } 16 \\
\text { are on a regulation of a } \\
\text { PA) }\end{array}$ & $\begin{array}{l}30 \text { (from which } 25 \text { are } \\
\text { on individual MPs } \\
\text { assigned to a different } \\
\text { PA; } 5 \text { are general on a } \\
\text { group of MPs assigned } \\
\text { to a group of PAs) }\end{array}$ & $\begin{array}{l}9 \text { (from which } 7 \text { are } \\
\text { on individual MPs } \\
\text { assigned to a } \\
\text { different PA; } 2 \text { are } \\
\text { general on a group } \\
\text { of MPs assigned to } \\
\text { a group of PAs) }\end{array}$ \\
\hline $\begin{array}{l}\text { Consultation reports } \\
\text { (Total - pages) }\end{array}$ & 50 & 120 & 16 & 5 \\
\hline $\begin{array}{l}\text { Protected Areas PA } \\
\text { (Total - no.) }\end{array}$ & 39 & 46 & 25 & 7 \\
\hline
\end{tabular}

197 Consultation reports of the cultural ministry contained sparse information and identical text

198 and were therefore omitted. The transportation ministry did not compile any consultation reports,

199 although transportation infrastructure crosses many protected areas, and conflicts exist (Pătru-

200 Stupariu et al., 2015). The ministry argues that Romania's General Transport Master Plan

201 includes sections on biodiversity conservation (Mobbs et al., 2014) and that a consultation report

202 from that agency is therefore unnecessary. 
The local public authorities did not deliver consultation reports. This may result from the fact

204 that local public authorities are not usually involved in conservation actions (Rozylowicz et al., 205 2017).

206 The consultation reports delivered by the non-governmental organization (NGOs) were not 207 included in the analysis due to their limited number. NGOs usually are not interested to 208 participate in this last step of inter-institutional consultation (Figure 1). They are active 209 participants in an earlier step (when the management plans need to get the environmental 210 approval from the national or local environmental protection agencies (EPAs), Figure 1), 211 specifically in SEA (Strategic Environmental Assessment) consultation. The NGOs also 212 participate in the development of management plans (Rozylowicz et al., 2017) especially when 213 they are developed within EU projects (Cent et al., 2014). Furthermore, often the NGOs are 214 themselves the managers of protected areas (21\% of the total number of protected areas 215 (Manolache et al., 2017; Ministry of the Environment, 2016)). This explains why in this last step 216 of inter-institutional consultation only few reports were delivered by NGOs. The NGOs likely 217 react in this last step only when: (i) serious issues raise (i.e., the management plans do not take 218 into account a certain category of local population whose interests the NGOs are representing); 219 or (ii) when they may be in conflict with the managers of the protected areas (such as EPAs, 220 forestry agencies, county councils, universities etc.). In Romania, the former communist 221 government has marginalized the impact of the NGOs. However, in recent years the NGOs are 222 increasingly becoming engaged in the protection and conservation of the natural resources 223 (Rozylowicz et al., 2017).

\section{2.3.Self-organizing map}


We organized and visualized the content of the consultation reports by using the Self-

Organizing Map (SOM), an unsupervised artificial neural network developed by Teuvo Kohonen

227 (Kohonen, 1981). We chose this method because it allows to extract patterns from unstructured

228 data, including textual documents, and classifies their content into topics. It is a visualization

229 clustering method, which maps high dimensional and complex data in a low dimensional grid of

230 nodes, known as neurons (usually two-dimensional) (Kohonen, 2001). In the resultant grid (the

231 output space, i.e., Figures 2-5) the topological relations that exist in the original data (the input

232 space, specifically the consultation reports) are preserved and mapped accordingly.

233 SOM has been widely used with documents as the input data (Lei and Kelly, 2015; Mayer

234 and Rauber, 2011) and is a useful tool for document classification based on content (Isa et al.,

235 2009). SOM is a clustering method, superior to traditional clustering because it employs a more

236 rigorous grouping procedure and does not assuming the existence of a particular number of

237 groups (Jain et al., 1996). It is an alternative to content analysis because it does not require $a$

238 priori knowledge of the data structure or a coding guide (Lei and Kelly, 2015).

239 To work with the data from a document, SOM converts the words into a set of vectors by

240 assigning weights. This is done by counting the frequency of the words in a document (Mayer

241 and Andreas, 2011). During the training procedure, a sample vector from the input data set is

242 compared with the weight vectors using some distance measure to find the best-matching unit

243 (Kohonen, 2001). Therefore, documents are grouped together in the resultant map based on the

244 similarity of their semantic content and the words are displayed close to one another according to

245 their importance in the document.

246 SOM has been applied in a broad array of studies in natural resources for the examination of

247 public discussions in a collaborative natural resource management process (Lei and Kelly, 2015), 
to predict the outlet concentrations of nutrients in integrated constructed wetlands by using water

249 quality variables (Zhang et al., 2008), to identify the factors that characterize the risk of pine

250 forests being affected by insect pests (Park et al., 2013) as well as to analyse the

251 interrelationships of multidimensional soil data (Merdun, 2011).

\subsubsection{Data pre-processing}

To create SOMs of optimal quality, the input documents must be pre-processed. First, the consultation reports were scanned as Portable Document Format (PDF) files and then converted

to ASCII format. Second, the documents were split up into 152 consultation reports as explained

256 in section 2.2. (Table 1), because a single document often contained the consultation reports for

257 multiple protected areas. The length of the consultation reports ranged from a few sentences to 258 hundreds of sentences. Finally, we used the text mining (tm) (Feinerer, 2015) and SnowballC 259 packages (Bouchet-Valat, 2014) in the R software (Team RC, 2014) to remove the punctuation 260 marks and numbers, convert the text to lower case, remove the auxiliary verbs and the very 261 commonly used words in the Romanian language as well as to convert the words to their stem 262 words. The SnowballC package implements a stemming algorithm described in Porter (1980) for 263 the Romanian language (i.e., "med" is the stem word for "mediu","mediului" which is the word 264 for "environment"). Keeping the documents in the Romanian language enabled us to keep the 265 language specifics.

\subsubsection{Vectorization and training}

The pre-processed documents were converted to vectors using the SOMLib parser script

268 included in the Java SOMToolbox developed at the Institute of Software Technology and

269 Interactive System at the Vienna University of Technology

270 (http://www.ifs.tuwien.ac.at/dm/somtoolbox/, (Mayer and Andreas, 2011)). The vectors 
271 (represented by the weights assigned to the words) were calculated by setting thresholds for

272 specific parameters, such as the minimum and maximum frequency for a word in a document to

273 be included or removed from the feature space. The thresholds were adjusted (lowered or raised)

274 for each training process until a reasonable dimensionality of the feature space was achieved. For

275 example, we used a minimum document frequency of 5 documents, so that those words included

276 in at least $5 \%$ of the documents were kept in the analysis, and a maximum document frequency

277 of 0.6 , so that those words that appeared in more than $60 \%$ of the documents were removed from

278 the feature space. This conversion process allowed us to remove the stop words remaining from

279 the text mining pre-processing, including those words with less than three characters, or those

280 which appear too frequently or too rarely in the documents. The resulted vectors were used to

281 train the SOM map (Kohonen, 2001). The training parameters for Java SOMToolbox included a

282 random seed of 7, a learning rate of 0.7 and 1500 iterations (Mayer and Andreas, 2011). A

283 rectangular map of the size of $20 \times 14$ neurons (or nodes) (a total of 280 neurons) was trained

284 using the Java SOMToolbox.

$285 \quad$ 2.3.3. Visualization

286 The resultant map was separated into clusters using Ward's clustering algorithm, which is an

287 agglomerative hierarchical clustering procedure that treats each node on the map as a separate

288 cluster. Next, clusters with minimum Euclidean distances between them were combined into

289 groups until a single cluster emerged on the SOM map (Yorek et al., 2016). Next, we used the

290 labelling method (Merkl and Rauber, 1999) which automatically generated labels for the SOM

291 map to identify the most prominent words in each cluster. Furthermore, the Java SOMToolbox

292 offers a set of SOM visualizations to discover structures in the data. We used the Cluster Map in

293 which the input data was divided into a number of clusters and (ii) the smoothed data histogram 
294 (SDH) which shows the smoothed data density on the map, allowing cluster identification in the 295 data (Pampalk et al., 2002).

\section{$296 \quad$ 2.3.4 Interpretation}

297 In each SOM visualization, a cluster is a delimited area on the map which contains

298 documents with similar content. Two words per cluster gave details about the content: the larger

299 word (i.e. the heading of the cluster) reflected the key information content of the specific cluster

300 while the smaller word provided additional information. Together they defined the topic of the

301 cluster. For example, in Figure 3(a) the heading 'pastures' shows that pastures management is an

302 important topic, while the word 'sowing' shows that sowing, an agricultural activity conducted

303 on pastures, have to be done in certain conditions. In the current study, clusters and topics belong

304 to each other. Each cluster has one topic. The original words in the Romanian language are

305 displayed in Appendix A. A larger cluster indicated a higher number of consultation reports that

306 mapped into that cluster. Neighbouring clusters may show more related topics than distant

307 clusters.

308 The Cluster Map was used to display the general landscape of the topics discussed in the

309 consultation reports, showing the most important (prominent) topics. The Smoothed data

310 histogram was used to identify the topics that were the most consistently (regularly) discussed in

311 the consultation reports.

312 We looked for cross-sector issues in the topics that emerged. We considered a cross-sector

313 issue as (i) any issue referring to how a ministry's interests interfered with nature conservation

314 and (ii) any attempt to harmonize a ministry's practice or legislation with nature conservation.

315 The issues that did not reflect a cross-sector approach but aimed to enhance plans content quality 
316 (i.e., the length and clarity of sentences, correct spelling, use of adequate maps and images) were

317 considered formal issues.

\section{3. Results}

\section{3.1.Topics in the consultation reports of the ministry of environmental protection}

320 The Cluster Map (Figure 2a) showed eight clusters representing distinct topics. subchapters structure, the avoidance or use of specific fonts (i.e., bold letters; roman letters for landscape units abbreviations), updating the names of institutions and the replacement of terms, expressions or legislation. These were discussed in documents that are clustered in the topics with the headings "surfaces" "order" and "bold" (Figure 2a,b).

Other topics referred to cross-sector issues because they addressed forests, hunting and

327 biodiversity which are domains in the ministry of environmental protection. For example, several

328 reports called for additional sections related to (i) the process for forest landowners'

329 consultations, i.e., that concerned landowners had to agree with the restrictions imposed by 330 protected area regulations, (ii) collaborative actions with other institutions and (iii) the addition 331 or updating of information about biotic factors, such as plant and animal species and habitats in 332 natural reserves (i.e., a category of protected areas), and data about habitat surfaces. Some 333 reports pinpointed shortcomings related to the weak link between the proposed activities in the 334 management plans and the conservation objectives. The most consistently discussed topics, as 335 shown by the smoothed data histogram (Figure $2 \mathrm{~b}$ ), were related to poaching and clear-cutting 336 pressure. Requirements for such pressures to be revised occurred often, because the actual 337 pressures were considered those related to agricultural activity as the protected areas under 338 evaluation did not include forests, being located on agricultural lands. Requests were made to 
339 rephrase the statement that "clear rules regarding the fight against poaching are lacking in the

340 hunting field", because it was "not a true statement" according to the Hunting Law. These cross-

341 sector issues were discussed in documents that are clustered in the topics with the headings

342 "conservation", "information", "reserves", "actions", and "hunting" (Figure 2a,b).

343

344
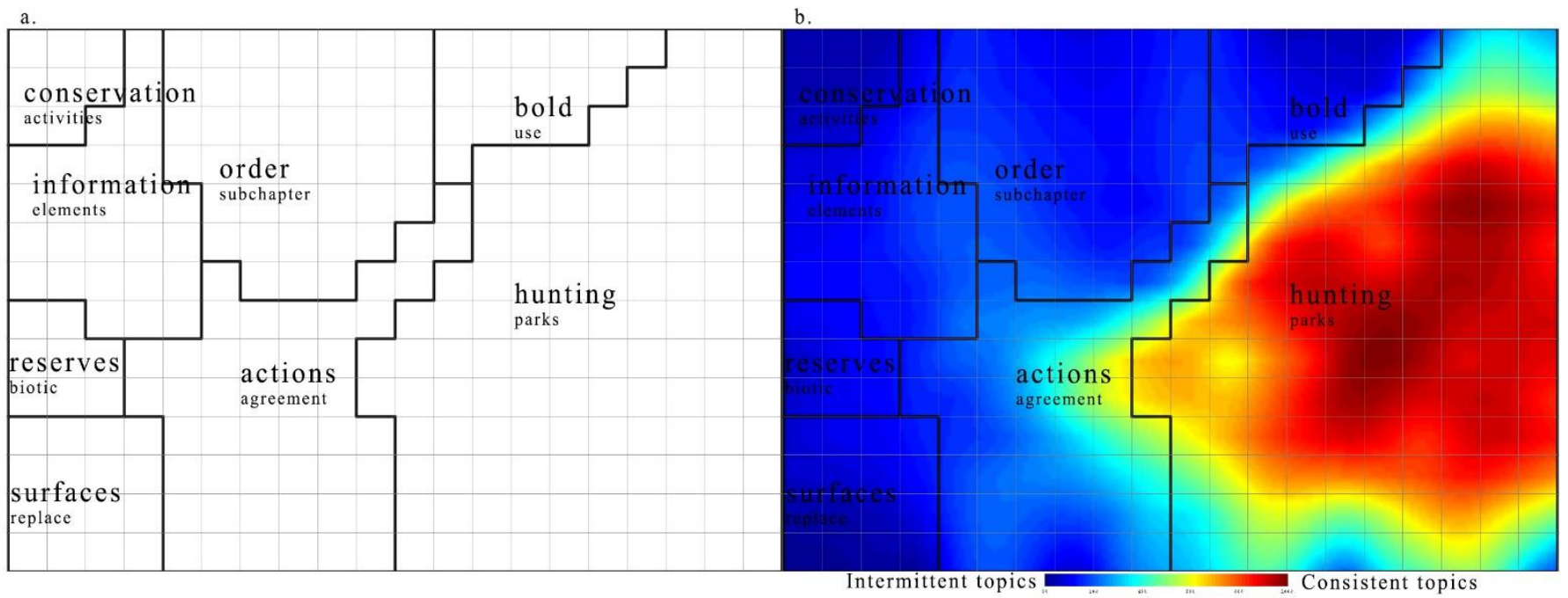

Figure 2: (a) A Cluster Map showing eight clusters labelled by the two most prominent words; (b) A Smoothed Data Histogram showing the most consistently/intermittently discussed topics by the ministry of environmental protection.

\subsection{Topics in the consultation reports of the ministry of agriculture}

The Cluster Map (Figure 3a) showed ten clusters representing distinct topics.

All topics referred to requests for harmonizing legislation and practices between agriculture and nature conservation. The topics focused on agricultural activity such as sowing, grazing and mowing conducted on grasslands (hay meadows and pastures). The consultation reports requested that attention be paid to certain issues. For example, the reports requested that the plan should emphasize that sowing is not permitted on pastures unless they are degraded or accidentally damaged. Another example is requests about grazing-related activities that go 
355 beyond the requirements of existing legal norms, such as "grazing is limited to a maximum of

356 one large animal unit per hectare". These were discussed in documents that are clustered in the

357 topics with the headings "pastures", "grazing" and "meadow" (Figure 3a,b). Furthermore, the

358 reports requested that the regulations concerning the use of fertilizer near water bodies or

359 regulations about woody vegetation on agricultural land should be removed from the

360 management plans because these regulations overlapped with measures specified by the National

361 Strategy for Rural Development, or other legal acts. Specifically, such a request was formulated

362 as, "please remove the regulations regarding the use of fertilizer on lands adjacent to water, as it

363 is regulated by the code of good agricultural practices concerning the protection of water against

364 pollution caused by nitrates from agricultural sources." The ministry further emphasized which

365 agricultural activities are already forbidden in protected areas (i.e., mowing at specific times "no

366 later than on the $1^{\text {st }}$ of June" and altitudes "on medium and low altitude pastures"; burning

367 vegetation close to forest habitats) based on legal acts and asked that the natural resource

368 manager update the related information. All these were discussed in documents that are clustered

369 in the topics with the headings "pastures", "water", "keep", "remove" and "habitat" (Figure 3a,b).

370 The smoothed data histogram (Figure 3b) shows that the most consistently discussed topics were

371 those related to the agricultural lands next to natural and scientific reserves since these areas

372 were affected by restrictions. Therefore, the requests were made to add specific legal rules

373 referring to compensation payments into the plans. These were contained in the cluster under the

374 heading "reserves" (Figure 3a,b). 


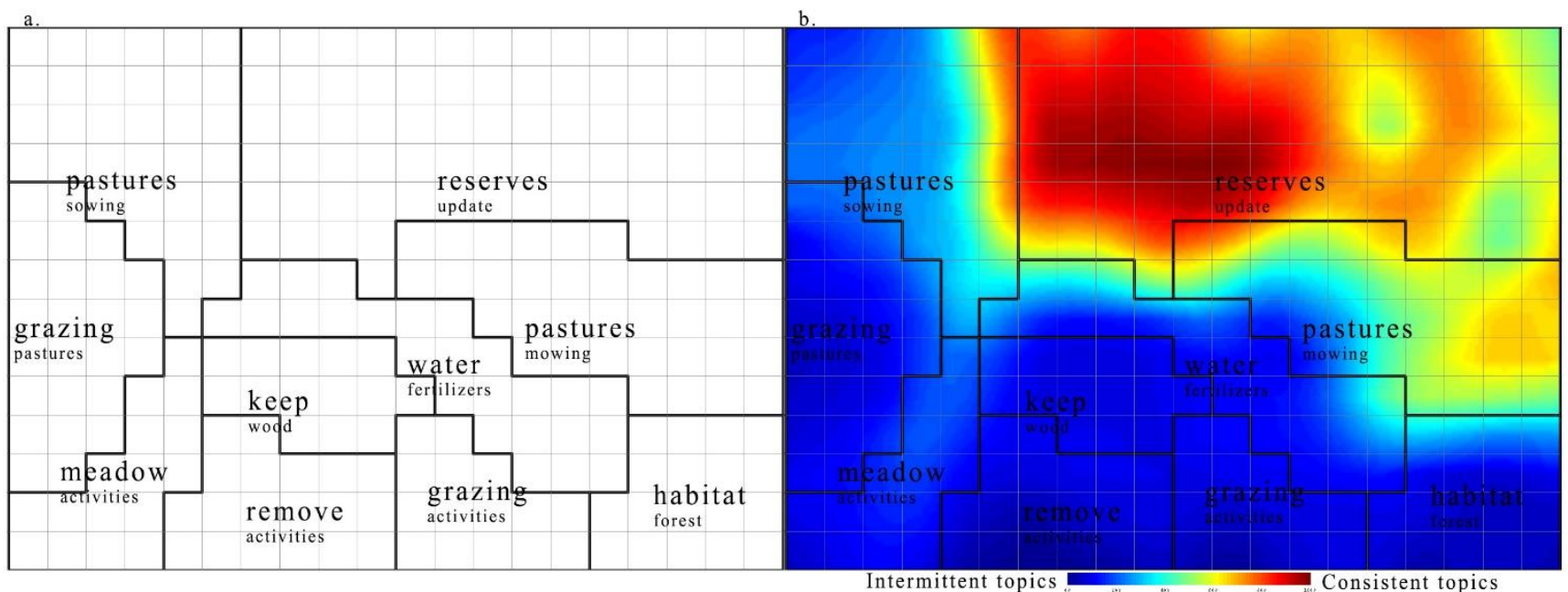

Figure 3: (a) A Cluster Map showing ten clusters labelled by the two most prominent words; (b) A

Smoothed Data Histogram showing the most consistently/intermittently discussed topics by the ministry of agriculture.

\subsection{Topics in the consultation reports of the ministry of spatial planning}

The cluster map (Figure 4a) showed seven clusters representing distinct topics.

Two of the topics displayed showed requests regarding the structure of the management environment, which was often changed to better reflect its purpose (i.e., from Ministry of the aspects that should be reworded (i.e., when sentences are ambiguous and the terminology of specific legal norms were not respected) or added (i.e., a legend in the appendices, or graphic and cartographic information). These were discussed in documents that are clustered in the topics with the headings "appendices" and "zoning" (Figure 4a,b).

Other topics that emerged referred to cross-sector issues because they referred to statements 
spatial and urban documents as well as the development plans with information regarding the

393 boundary and location of the protected areas. These encompassed the clusters "reserve", "SCIs",

394 "authorities" and "plans" (Figure 4a,b). Furthermore, the smoothed data histogram (Figure 4b)

395 showed that the most consistently discussed topics were related to the internal zoning of the

396 protected areas. In some protected areas, the zoning was absent, and it was not clear which

397 activities were allowed in the various zones and which standards construction should meet to be

398 allowed in a sustainable development zone according to the current legal framework. These were

399 discussed in documents that are clustered in the topics with the headings "allow" and "zoning"

400 (Figure 4a,b).

401

402

403

404

405

406

407

408

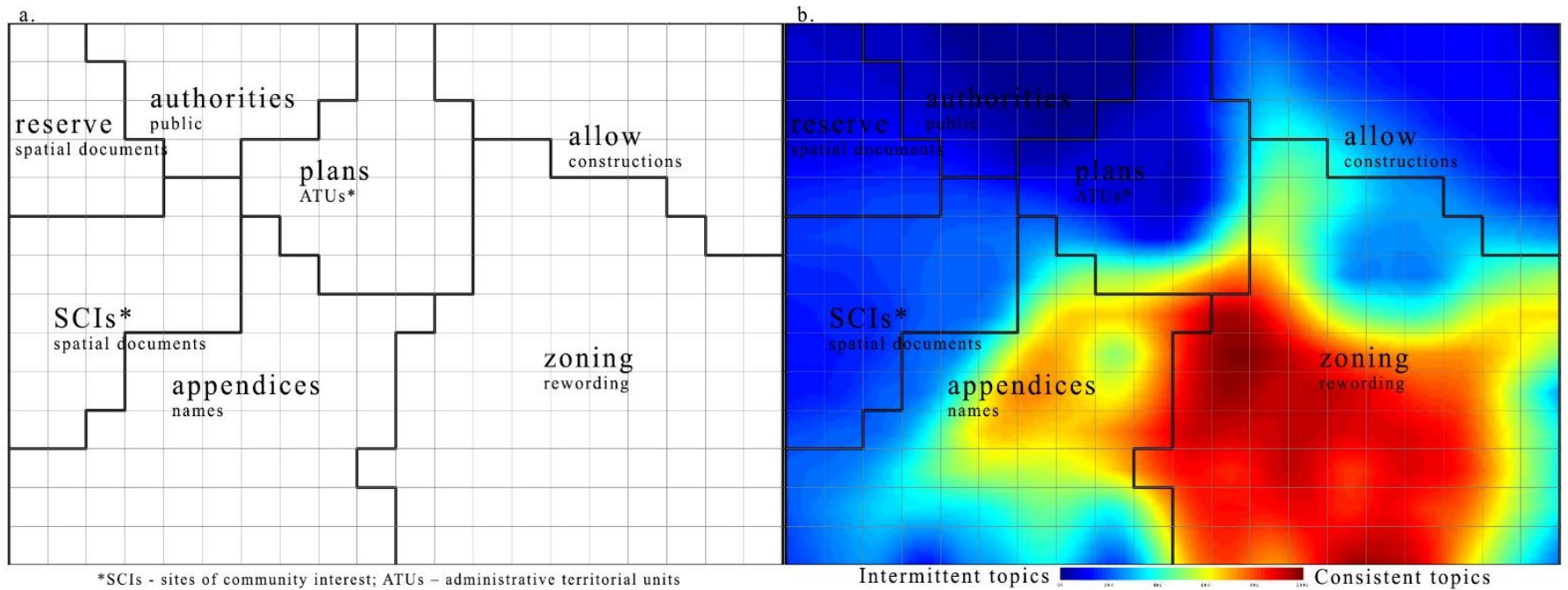

Figure 4: (a) A Cluster Map showing seven clusters labelled by the two most prominent words;

(b) A Smoothed Data Histogram showing the most consistently/intermittently discussed topics by the ministry of spatial planning.

\subsection{Topics in the consultation reports of the ministry of security}

The cluster map (Figure 5a) showed six clusters representing distinct topics.

Two topics referred to requests about the structure of the plans, for which suggestions were made about avoiding the use of unsuitable terms (i.e., "central public authority for environmental 
409 protection instead of central public authority for environmental and forests protection"), the 410 replacement of the name of an institution (i.e., from "Prefecture to Prefect's Institution") or 411 updating the number of the custody convention (the official document through which a 412 management plan is assigned to a custodian). These were discussed in documents that are 413 clustered in the topics with the headings "unsuitable" and "convention" (Figure 5a,b).

414 Four other topics that emerged referred to cross-sector issues. The consultation reports 415 addressed security (police attributions) in the protected areas, the need for the vaccination of 416 police dogs that access the protected areas as well as appropriate means of intervention and 417 precautions to overcome the potential effects of natural disasters. For example, a consultation 418 report stated, "Prohibition against the use of open fire for various activities in the protected areas 419 must be included in the management plans". Furthermore, requests were made in the 420 consultation reports to include the Prefect's Institution (i.e., an institution subordinated to the 421 ministry) on the list of the institutions that must be involved in the development of the 422 management plans because the ministry considers that Prefect's Institution will have an 423 important role in guaranteeing spatial development and environmental safety. Furthermore, "the

424 Prefect's Institution will contribute to the implementation of the management plans by 425 coordinating the actions that different local institutions are taking and by facilitating 426 communication with state institutions". The smoothed data histogram (Figure 5b) shows that the 427 most consistently discussed topics were those related to updating the attributions of the police 428 units in terms of the intervention plans as well as listing the name of the people that enforce 429 sanctions in the protected areas. These were discussed in documents that are clustered in the 430 topics with the headings "security", "dogs", "disaster" and "institution" (Figure 5a,b). 


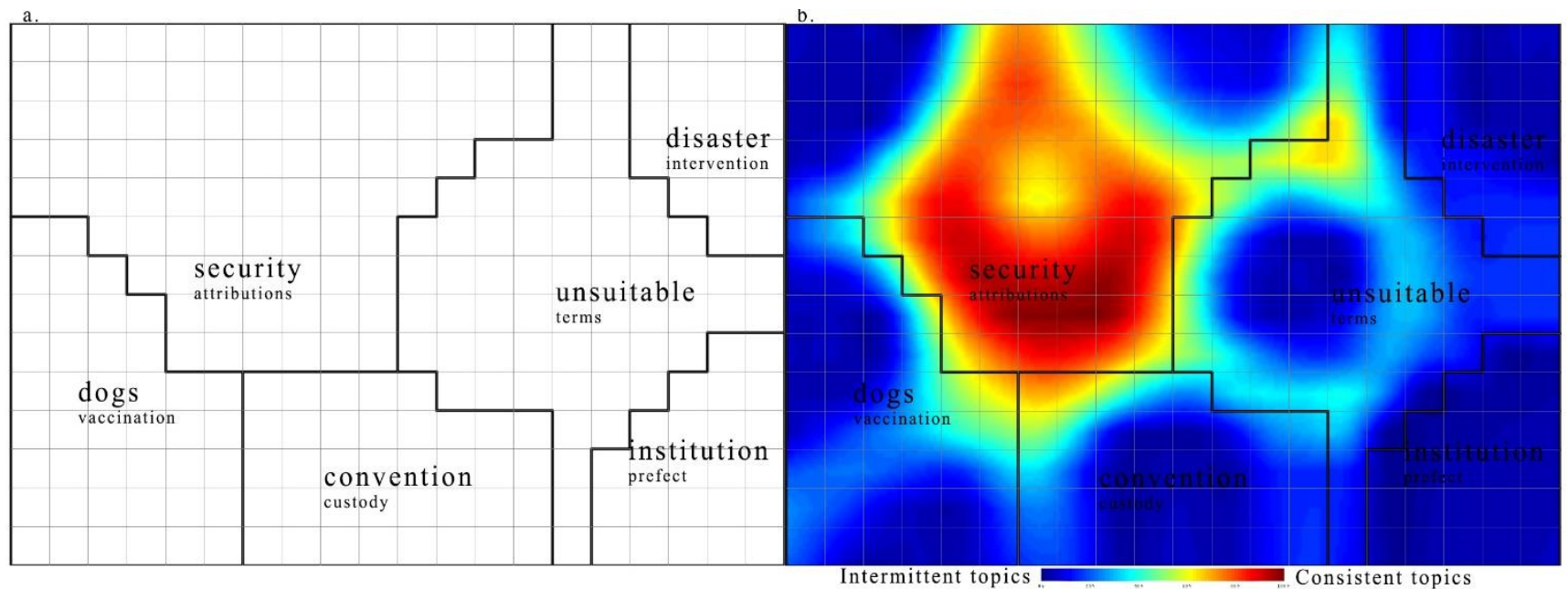

Figure 5: (a) A Cluster Map showing six clusters labelled by the two most prominent words; (b) A

433 Smoothed Data Histogram showing the most consistently/intermittently discussed topics by the ministry 434 of security.

\section{Discussion and Conclusions}

The governance of a protected area requires robust knowledge about the biodiversity of the area as well as strong collaboration between multiple stakeholders to achieve the envisioned nature conservation goals. In case of transition countries, participation in protected areas management is taking place usually at national level (Brescancin et al., 2017) but cooperation between different state actors seems to be a major problem (Kluvankova-Oravska et al., 2009) as a result of a misfit

441 between conservation policies and other policies (Wesselink et al., 2011).

In order to better understand coordination among different sectors represented by ministries,

443 we analysed a large sample of consultation reports about management plans for protected areas

444 from the most relevant ministries and assessed the extent to which they focus on cross-sector 445 issues. In addition to exploring the cross-sector issues in the consultation reports (and documenting 446 the situation in a country that just starts to gain experiences with cross-sector coordination) we 447 found a strong focus on formal issues, such as corrections to the structure and wording of the plans, 
448 in many consultation reports. This focus on formal issues can have different reasons, such as the

449 stakeholders writing the reports do not want to address the real conflicting issues; or they do not

450 understand the purpose of the reports; or the cross-sector interests are already optimally 451 coordinated in the plans, and that is why these are not addressed in the reports; or these comments

452 on formal issues are part of the process of ensuring that common concepts and thinking are used

453 in all sectors which enhances policy consistency. This shows that such formal comments can be 454 important and should be further analysed as they could provide useful insights.

455 Furthermore, we found differences between ministries regarding the most important topics 456 discussed in the consultation reports. While both cross-sector and formal issues were predominant 457 in the consultation reports of ministries of environmental protection, spatial planning and security, 458 the harmonization of practices and legislation dominated the consultation reports of the ministry 459 of agriculture.

460 When the whole dataset was considered, similar issues emerged as in the individual 461 consultation reports (Figure 6). These were related to forest landowner consultation, harmonization 462 of agricultural and forestry practices as well as harmonization of spatial plans with conservation. 463 However, agricultural practices, especially those that refer to the management of pastures, were 464 often asked to be reviewed according to the existing agricultural regulations. This topic dominated 465 most of the clusters in Figure 6, which might result from the fact that the ministry of agriculture 466 delivered the highest number of consultation reports. 


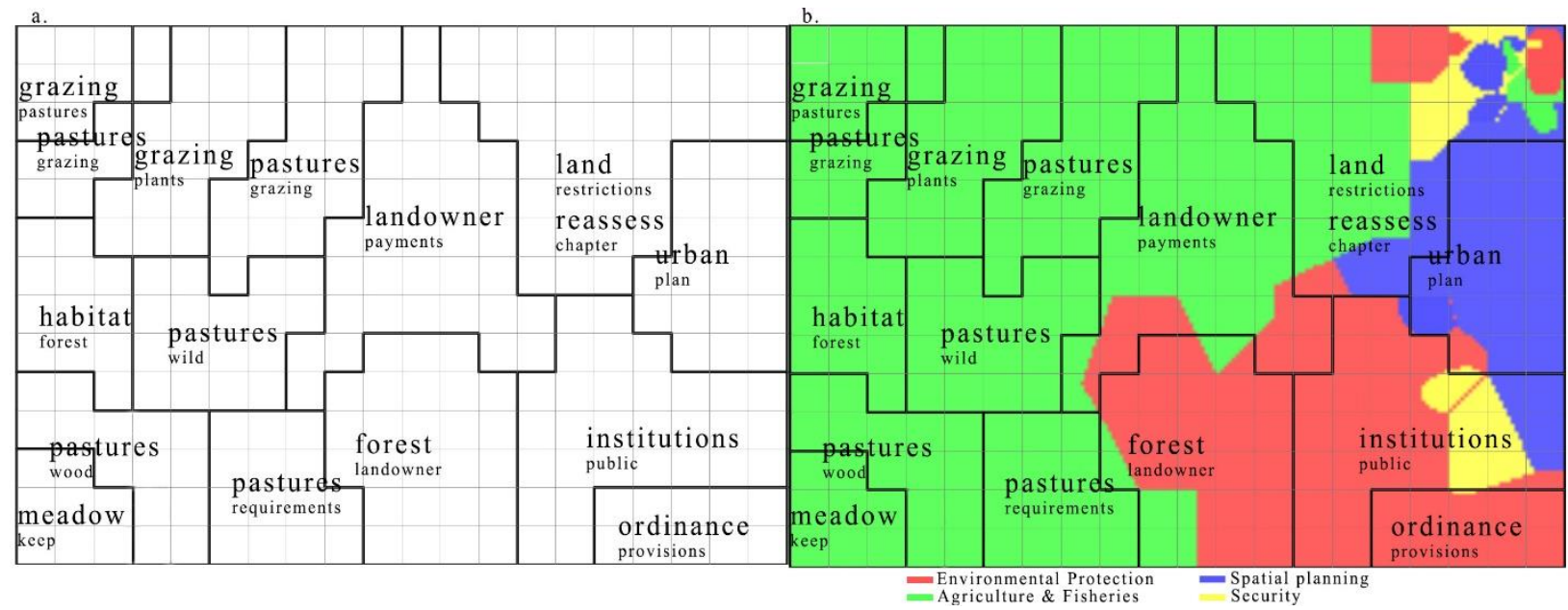

Figure 6: (a) A Cluster Map showing fifteen clusters labelled by the two most prominent words;

(b) A Smoothed Data Histogram showing the most consistently/intermittently discussed topics

by all four ministries.

The content of the consultation reports revealed that forest landowners, who are important

472 stakeholders in a management plan, were not informed about restrictions on forest use, which

473 should be put in practice only after agreement by the landowners. Furthermore, the consultation

474 reports stated that the plans included false data regarding forest landowners, and no information

475 about compensation for the landowners affected by the restrictions which may subsequently lead

476 to the total or partial contestation of the plans before their approval by the ministry of the

477 environment. Indeed, the restrictions on forest use imposed by the management plans fuelled

478 conflicts (Redpath et al., 2013). Our finding regarding the lack of consultation of the most

479 important stakeholders confirmed a general deficiency. Public participation and consultation in

480 protected area management plans is rare in Romania as a result of a top-down approach in

481 protected area planning (Ioja et al., 2016), a lack of conservation awareness of landowners

482 (Hersperger et al., 2015), weak local institutions (Hartel et al., 2014) as well as a lack of

483 governmental incentives for participation (Stringer and Paavola, 2013). The lack of proper 
484 compensations for landowners made them to evoke negative attitudes (Szell, 2012) toward

485 Natura 2000 network which have hindered their involvement in participatory processes (Cent et

486 al., 2014). Furthermore, the pre-established management rules established in the plans may

487 hinder public consultation because people are afraid that only limited modifications to a plan can

488 be made (Bockstael et al., 2016).

489 There seemed to be a strong interest in coherent and consistent plans in terms of overlapping 490 practices because the ministry coordinates the National Strategy for Rural Development since

491 Romania's entrance into the European Union in 2007. This strategy makes possible, through the

492 financial support of specific measures, the development of the agricultural sector and rural areas.

493 As through this strategy measures are already established for the management of natural

494 resources, the ministry requested the harmonization between these measures and those proposed

495 in the newly developed management plans. The ministry of agriculture wants to remain as the

496 agency that provides compensatory payments to farmers even in protected areas. Specifically, the

497 comments in the consultation reports were geared towards preventing a shift of this

498 responsibility to the ministry of environmental protection, which is responsible for managing the 499 country's protected areas.

$500 \quad$ Furthermore, requests were made to include information about protected areas in the spatial 501 and urban plans. This is an important issue because one requirement for the approval of a spatial 502 urban plan is to be in accord with the objectives of protected area management plans.

503 Some surprises revealed by the SOM method refer to the role of security officers (i.e., the 504 police and gendarmerie) in the enforcement of regulations in protected areas which has been 505 emerged as being unclear in the plans. Therefore, the management plans could be an opportunity 506 to bring this issue into the political arena. Other surprises refer to formal issues that were 
regularly discussed in the consultation reports. Most of them address changing fonts, adding

508 diacritical marks to letters, a bibliography, rewording terms or updating names. The consultation

509 reports in which such issues prevail might have been written by lawyers, who focused rather on

510 aligning the content of the management plan with a ministry's legal framework than on cross-

511 sector issues.

$512 \quad$ Practical suggestions

513 The analysis revealed that the consultation reports did not provide comprehensive coverage

514 of relevant cross-sector issues. To take full advantage of inter-institutional consultation, we

515 suggest the ministries should focus more on (i) identifying which conservation activities are

516 incompatible or may fuel conflict, (ii) proposing specific conservation activities for a protected

517 area under evaluation, when such actions are formulated too generally in the plan, and (iii)

518 providing best practices for protected areas management. One way to improve inter-institutional

519 consultation could be to integrate it earlier in the process, specifically during the preparation of

520 the management plans, as it is conducted in SEA (2001/42/EC). Although in Romania the

521 decision-making process has made progress toward a consultative approach, it turns out that

522 consultation remains more a formal step than inclusive activity (Matei and Dogaru, 2013). This

523 focus on formal issues may come from ministries' reluctance to interact with other public

524 administrations and private stakeholders (Matei and Gaita, 2016).

525 To harmonize the national development policies with the conservation policies and avoid 526 further conflict, all important areas (i.e., industry, forestry, agriculture, defence, transportation, 527 etc.) must collaborate. In Romania, the lack of collaboration between different stakeholders in 528 conservation matters may arise from an emphasis on economic rather than ecological goals 529 (Grădinaru et al., 2017; Tudor et al., 2015, 2014), and the government's reluctance for more 
530 inclusive environmental governance approaches (Stringer and Paavola, 2013). Furthermore, the

531 legacy of the Romania`s communist past may also be a reason for the less effective opening of

532 institutions for collaboration (Stringer and Paavola, 2013).

533 The harmonization of other policies with nature conservation policies is also difficult in other

534 countries which are experiencing rapid economic development and are heavily dependent on

535 natural resources (Chunmei and Zhaolan, 2010), where nature conservation is influenced by biding

536 or non-binding international norms (Hiedanpää and Bromley, 2011), or in countries where the

537 most effective policy entrepreneurs are influential economic stakeholders. However, consultation

538 reports may provide a suitable venue for dealing with cross-sector issues.

539 Protected-area managers and ministries may take advantage of SOMs of consultation reports

540 as developed in this study. These maps might facilitate the development of future management

541 plans (almost half of the Romania's protected areas do not still have a management plan) because

542 the maps indicate which topics are of the most concern to the ministries. Managers might react

543 accordingly by developing specific plans, which in turn might accelerate the process of

544 management plan approval. Showing these maps to ministries is important to allow them to

545 understand the focus of their consultation reports and adapt future reports by focusing more on

546 harmonizing their policies with the management plans than on formal issues.

547 The formal issues that emerged from the consultation reports could be included in a standard

548 for the preparation of the management plans. This would eventually improve the quality of the

549 management plans and help to focus consultation reports on relevant and substantial issues.

550 The SOMs have been demonstrated to be useful for identifying the information in the

551 consultation reports. Furthermore, SOMs can be applied to any domain and almost any type and

552 amount of data, especially to very large data sets (Olteanu and Villa-Vialaneix, 2015). As it is an 
unsupervised learning algorithm, no a priori knowledge on both domain and input data is

554 required. Despite the unsupervised nature of the SOMs, a strong familiarity with the consultation

555 reports is required to properly interpret the results. SOMs potential has been exploited in

556 retrieving information from websites content (Chifu and Letia, 2010), complex ecological data

557 (Chon, 2011), environmental quantitative data (Tran et al., 2003), and even music and images

558 (Mayer, 2011). SOMs applicability to predict and produce management practices has been

559 shown by Zhang et al., (2008) who used SOM to predict nutrient removal in integrated

560 constructed wetlands. So far SOM has been mainly used for visualizing and clustering

561 nonhomogeneous and complex data. Considering clustering quality, there is no overall

562 agreement that SOM produces the best clusters (Kohonen, 2001) as compared with other self-

563 organizing hybrid algorithms (Isa et al., 2009). Furthermore, as SOM, and any other clustering

564 method, deals with dimension reduction, some information may be lost. Therefore, scholars have

565 proposed several extensions of SOM algorithm (Olteanu and Villa-Vialaneix, 2015) and even

566 used SOM in combination with other methods (such as PCA, linear regression analysis, genetic

567 algorithms) to counteract such shortcomings.

568 Future research can examine the consultation reports of various departments subordinated to

569 the same ministry. This might highlight common or conflicting views regarding nature

570 conservation across departments. Future research could also assess the consultation reports from

571 NGOs in an earlier step in the process so a more complete view of stakeholders' concerns

572 regarding protected area management plans could be attained.

573 Exploring consultation reports from various ministries has been useful to gain an

574 understanding of the issues that most concern the ministries regarding nature conservation.

575 Monitoring the topics of these reports may help protected area management in the future by 
576 revealing the most important issues that require careful consideration to ensure the effective

577 implementation of nature conservation policies.

\section{Acknowledgements}

This work was supported by the Romanian National Authority for Scientific Research, UEFISCDI [PN-II-RU-TE-2014-4-0673]. 


\section{References}

Apostolopoulou, E., Pantis, J.D., 2009. Conceptual gaps in the national strategy for the implementation of the European Natura 2000 conservation policy in Greece. Biol. Conserv. 142, 221-237. doi:10.1016/j.biocon.2008.10.021

Avdibegović, M., Marić, B., Bećirović, D., Delić, S., Bećirović, S.M., 2015. Cross-sectoral cooperation in management of national park Una. Work. Fac. For. Univ. Sarajev. 66-86.

Barthel, S., Crumley, C., Svedin, U., 2013. Bio-cultural refugia-Safeguarding diversity of practices for food security and biodiversity. Glob. Environ. Chang. 23, 1142-1152. doi:10.1016/j.gloenvcha.2013.05.001

Berkes, F., 2010. Devolution of environment and resources governance: trends and future. Environ. Conserv. 37, 489-500. doi:10.1017/S037689291000072X

Bockstael, E., Bahia, N.C.F., Seixas, C.S., Berkes, F., 2016. Participation in protected area management planning in coastal Brazil. Environ. Sci. Policy 60, 1-10. doi:10.1016/j.envsci.2016.02.014

Borrini-Feyerabend, G., Hill, R., 2015. Governance for the conservation of nature, in: Worboys, G., Lockwood, M., Kothari, A., Feary, S., Pulsford, I. (Eds.), Protected Area Governance and Management. ANU Press.

Bouchet-Valat, M., 2014. Snowball stemmers based on the C libstemmer UTF-8 library.

Brescancin, F., Dobšinská, Z., De Meo, I., Šálka, J., Paletto, A., 2017. Analysis of stakeholders' involvement in the implementation of the Natura 2000 network in Slovakia. For. Policy Econ. doi:10.1016/j.forpol.2016.12.010

Burby, R.J., 2003. Making Plans that Matter: Citizen Involvement and Government Action. J. Am. Plan. Assoc. 69, 33-49. doi:10.1080/01944360308976292

Cent, J., Grodzińska-Jurczak, M., Pietrzyk-Kaszyńska, A., 2014. Emerging multilevel environmental governance - A case of public participation in Poland. J. Nat. Conserv. 22, 93-102. doi:10.1016/j.jnc.2013.09.005

Chifu, E.S., Letia, I.A., 2010. Self-organizing Maps in Web Mining and Semantic Web, in: Matsopoulos, G.K. (Ed.), Self Organizing Maps.

Chon, T.-S., 2011. Self-Organizing Maps applied to ecological sciences. Ecol. Inform. 6, 50-61. doi:10.1016/j.ecoinf.2010.11.002

Chunmei, W., Zhaolan, L., 2010. Environmental Policies in China over the Past 10 Years: Progress, Problems and Prospects. Procedia Environ. Sci. 2, 1701-1712. doi:10.1016/j.proenv.2010.10.181

EC, 2016. Natura 2000 Barometer.

EC, 2012. EU Biodiversity Policy Development.

Feinerer, I., 2015. Introduction to the tm Package Text Mining in R.

GD No 561, 2009. for the approval of the Regulation on the procedures, at the Government level, for the elaboration, approval and presentation of draft policy documents, draft normative acts and other documents, in order to be adopted/approved.

Grădinaru, S., Iojă, C., Pătru-Stupariu, I., Hersperger, A., 2017. Are Spatial Planning Objectives Reflected in the Evolution of Urban Landscape Patterns? A Framework for the Evaluation of Spatial Planning Outcomes. Sustainability 9, 1279. doi:10.3390/su9081279

Hartel, T., Fischer, J., Câmpeanu, C., Milcu, A.I., Hanspach, J., Fazey, I., 2014. The importance of ecosystem services for rural inhabitants in a changing cultural landscape in Romania. Ecol. Soc. 19, art42. doi:10.5751/ES-06333-190242

Hersperger, A.M., Ioja, I.C., Steiner, F., Tudor, C.A., 2015. Comprehensive consideration of conflicts in the land-use planning process: a conceptual contribution. Carpathian J. Earth Environ. Sci. 10, 5-13.

Hiedanpää, J., Bromley, D.W., 2011. The harmonization game: Reasons and rules in European biodiversity policy. Environ. Policy Gov. 21, 99-111. doi:10.1002/eet.561

Hill, R., Davies, J., Bohnet, I.C., Robinson, C.J., Maclean, K., Pert, P.L., 2015. Collaboration mobilises institutions with scale-dependent comparative advantage in landscape-scale biodiversity conservation. Environ. Sci. Policy 51, 267-277. doi:10.1016/j.envsci.2015.04.014 
Innes, J.E., Booher, D.E., 2003. Collaborative policymaking: governance through dialogue, in: Hajer, M.A., Wagenaar, H. (Eds.), Deliberative Policy Analysis: Understanding Governance in the Network Society. Cambridge University Press, Cambridge.

Ioja, C., Nita, M.R., Hossu, C.A., 2016. Environmental Conflicts. Interdiscip. Perspect. Contemp. Confl. Resolut. doi:10.4018/978-1-5225-0245-6.ch004

Ioja, C.I., Patroescu, M., Rozylowicz, L., Popescu, V.D., Verghelet, M., Zotta, M.I., Felciuc, M., 2010. The efficacy of Romania?s protected areas network in conserving biodiversity. Biol. Conserv. 143, 2468-2476. doi:10.1016/j.biocon.2010.06.013

Isa, D., Kallimani, V.P., Lee, L.H., 2009. Using the self organizing map for clustering of text documents. Expert Syst. Appl. 36, 9584-9591. doi:10.1016/j.eswa.2008.07.082

Jain, A.K., Jain, A.K., Mao, J., Mohiuddin, K., 1996. Artificial Neural Networks: A Tutorial. Computer (Long. Beach. Calif). 29, 31-44.

Joppa, L., Baillie, J., Robinson, J.G., 2016. Protected areas: are they safeguarding biodiversity? WileyBlackwell.

Kluvankova-Oravska, T., Chobotova, V., Banaszak, I., Slavikova, L., Trifunovova, S., 2009. From government to governance for biodiversity: the perspective of central and Eastern European transition countries. Environ. Policy Gov. 19, 186-196. doi:10.1002/eet.508

Kohonen, T., 2001. Self-Organizing Maps, 3rd ed. Springer, New York.

Kohonen, T., 1981. Automatic formation of topological maps of patterns in a self-organizing system, in: Oja, E., Simula, O. (Eds.), . Proc. 2nd Scand. Conf. on Image Analysis, pp. 214-220.

Koontz, T.M., Newig, J., 2014. Cross-level information and influence in mandated participatory planning: Alternative pathways to sustainable water management in Germany's implementation of the EU Water Framework Directive. Land use policy 38, 594-604. doi:10.1016/j.landusepol.2014.01.005

Lei, S., Kelly, M., 2015. Evaluating Collaborative Adaptive Management in Sierra Nevada Forests by Exploring Public Meeting Dialogues Using Self-Organizing Maps. Soc. Nat. Resour. 28, 873-890. doi:10.1080/08941920.2015.1045645

Lockwood, M., 2010. Good governance for terrestrial protected areas: A framework, principles and performance outcomes. J. Environ. Manage. 91, 754-766. doi:10.1016/j.jenvman.2009.10.005

Mace, G.M., 2014. Whose conservation? Science (80-. ). 345.

Manolache, S., Ciocanea, C.M., Rozylowicz, L., Nita, A., 2017. Natura 2000 in Romania -a Decade of Governance Challenges. Eur. J. Geogr. Eur. Geogr. Eur. J. Geogr. 8, 24-34.

Matei, A., Dogaru, T.-C., 2013. Coordination of Public Policies in Romania. An Empirical Analysis. Procedia - Soc. Behav. Sci. 81, 65-71. doi:10.1016/j.sbspro.2013.06.389

Matei, A., Gaita, C., 2016. Characteristics of Process Management in the Public Institutions in Romania. Comparative Analysis. Procedia Econ. Financ. 39, 94-101. doi:10.1016/S2212-5671(16)30246-5

Mayer, R., 2011. Analysing the Similarity of Album Art with Self-Organising Maps, in: Honkela, J., Laaksonen, T. (Eds.), Advances in Self-Organizing Maps.

Mayer, R., Andreas, R., 2011. Java SOMToolbox (version 0.7.5-3 svn4280).

Mayer, R., Rauber, A., 2011. On Wires and Cables: Content Analysis of WikiLeaks Using SelfOrganising Maps, in: Laaksonen, J., Honkela, T. (Ed.), Advances in Self-Organizing Maps: 8th International Workshop, WSOM. pp. 238-246.

Merdun, H., 2011. Self-organizing map artificial neural network application in multidimensional soil data analysis. Neural Comput. Appl. 20, 1295-1303. doi:10.1007/s00521-010-0425-1

Merkl, D., Rauber, A., 1999. Automatic labeling of self-organizing maps for information retrieval, in: 6th International Conference on Neural Information Processing. IEEE, pp. 37-42. doi:10.1109/ICONIP.1999.843958

Ministry of the Environment, 2016. Database of natural protected areas [WWW Document]. URL www.mmediu.ro

Mobbs, I., Mohan, F., Clarke, G., Els, J., 2014. General Transport Master Plan for Romania.

Newig, J., Fritsch, O., 2009a. More Input - Better Output: Does Citizen Involvement Improve Environmental Governance?, in: Blühdorn, I. (Ed.), In Search of Legitimacy: Policy Making in 
Europe and the Challenge of Complexity. Farmington Hills, Opladen, Germany, pp. 205-224.

Newig, J., Fritsch, O., 2009b. Environmental governance: participatory, multi-level - and effective?

Environ. Policy Gov. 19, 197-214. doi:10.1002/eet.509

Newig, J., Schulz, D., Jager, N.W., 2016. Disentangling Puzzles of Spatial Scales and Participation in Environmental Governance?The Case of Governance Re-scaling Through the European Water Framework Directive. Environ. Manage. 58, 998-1014. doi:10.1007/s00267-016-0753-8

Nita, A., Rozylowicz, L., Manolache, S., Ciocănea, C.M., Miu, I.V., Popescu, V.D., 2016. Collaboration Networks in Applied Conservation Projects across Europe. PLoS One 11, e0164503. doi:10.1371/journal.pone.0164503

North, D.C., 1990. Institutions, institutional change, and economic performance, 1st ed. Cambridge University Press.

Olsen, E., Fluharty, D., Hoel, A.H., Hostens, K., Maes, F., Pecceu, E., 2014. Integration at the Round Table: Marine Spatial Planning in Multi-Stakeholder Settings. PLoS One 9, e109964. doi:10.1371/journal.pone.0109964

Olteanu, M., Villa-Vialaneix, N., 2015. On-line relational and multiple relational SOM. Neurocomputing 147, 15-30. doi:10.1016/j.neucom.2013.11.047

Orenstein, S., Moore, L., Sherry, S., 2008. Spectrum of processes for collaboration and consensusbuilding in public decisions.

Ostrom, E., 1990. Governing the commons: the evolution of institutions for collective action.

Pampalk, E., Rauber, A., Merkl, D., 2002. Using Smoothed Data Histograms for Cluster Visualization in Self-Organizing Maps, in: Artificial Neural Networks. Springer, Berlin, Heidelberg, pp. 871-876. doi:10.1007/3-540-46084-5_141

Park, Y.-S., Chung, Y.-J., Moon, Y.-S., 2013. Hazard ratings of pine forests to a pine wilt disease at two spatial scales (individual trees and stands) using self-organizing map and random forest. Ecol. Inform. 13, 40-46. doi:10.1016/j.ecoinf.2012.10.008

Pătru-Stupariu, I., Stupariu, M.-S., Tudor, C.A., Grădinaru, S.R., Gavrilidis, A., Kienast, F., Hersperger, A.M., 2015. Landscape fragmentation in Romania's Southern Carpathians: Testing a European assessment with local data. Landsc. Urban Plan. doi:10.1016/j.landurbplan.2015.06.002

Porter, M.F., 1980. An algorithm for suffix stripping. Program 14, 130-137. doi:10.1108/eb046814

Possingham, H.P., Grantham, H., Rondinini, C., 2007. How can you conserve species that haven't been found? J. Biogeogr. 34, 758-759. doi:10.1111/j.1365-2699.2007.01717.x

Redpath, S.M., Young, J., Evely, A., Adams, W.M., Sutherland, W.J., Whitehouse, A., Amar, A., Lambert, R.A., Linnell, J.D.C., Watt, A., Gutiérrez, R.J., 2013. Understanding and managing conservation conflicts. Trends Ecol. Evol. 28, 100-109. doi:10.1016/j.tree.2012.08.021

Reed, M.S., Dougill, A.J., Taylor, M.J., 2007. Integrating local and scientific knowledge for adaptation to land degradation: Kalahari rangeland management options. L. Degrad. Dev. 18, 249-268. doi:10.1002/ldr.777

Romanian Government, 2015. Ministry of the Environment.

Roux, D.J., Ashton, P.J., Nel, J.L., MacKay, H.M., 2008. Improving Cross-Sector Policy Integration and Cooperation in Support of Freshwater Conservation. Conserv. Biol. 22, 1382-1387. doi:10.1111/j.1523-1739.2008.01080.x

Rozylowicz, L., Nita, A., Manolache, S., Ciocanea, C.M., Popescu, V.D., 2017. Recipe for success: A network perspective of partnership in nature conservation. J. Nat. Conserv. 38, 21-29. doi:10.1016/j.jnc.2017.05.005

Schilling-Vacaflor, A., 2014. Rethinking the link between consultation and conflict: lessons from Bolivia's gas sector. Can. J. Dev. Stud. / Rev. Can. d'études du développement 35, 503-521. doi:10.1080/02255189.2014.967667

Spierenburg, M., 2012. Getting the Message Across Biodiversity Science and Policy Interfaces - A Review. GAIA - Ecol. Perspect. Sci. Soc. 21, 125-134. doi:10.14512/gaia.21.2.11

Staronova, K., Mathernova, K., 2003. Lessons from Slovakia's Transition Reform Process. Budapest, Hungary. 
Stringer, L., Paavola, J., 2013. Participation in environmental conservation and protected area management in Romania: A review of three case studies. Environ. Conserv. 40, 138-146. doi:10.1017/S0376892913000039

Stringer, L.C., Dougill, A.J., Dyer, J.C., Vincent, K., Fritzsche, F., Leventon, J., Falcão, M.P., Manyakaidze, P., Syampungani, S., Powell, P., Kalaba, G., 2014. Advancing climate compatible development: lessons from southern Africa. Reg. Environ. Chang. 14, 713-725. doi:10.1007/s10113-013-0533-4

Sutcliffe, L.M.E., Batáry, P., Kormann, U., Báldi, A., Dicks, L. V., Herzon, I., Kleijn, D., Tryjanowski, P., Apostolova, I., Arlettaz, R., Aunins, A., Aviron, S., Baležentienè, L., Fischer, C., Halada, L., Hartel, T., Helm, A., Hristov, I., Jelaska, S.D., Kaligarič, M., Kamp, J., Klimek, S., Koorberg, P., Kostiuková, J., Kovács-Hostyánszki, A., Kuemmerle, T., Leuschner, C., Lindborg, R., Loos, J., Maccherini, S., Marja, R., Máthé, O., Paulini, I., Proença, V., Rey-Benayas, J., Sans, F.X., Seifert, C., Stalenga, J., Timaeus, J., Török, P., van Swaay, C., Viik, E., Tscharntke, T., 2015. Harnessing the biodiversity value of Central and Eastern European farmland. Divers. Distrib. 21, 722-730. doi:10.1111/ddi. 12288

Szabo, E.A., Lawrence, A., Iusan, C., Canney, S., 2008. Participatory protected area management - A case study from Rodna Mountains National Park, Romania. Int. J. Biodivers. Sci. Ecosyst. Serv. Manag. 4, 187-199. doi:10.3843/Biodiv.4.4:2

Szell, A.B., 2012. Attitudes and Perceptions of Local Residents and Tourists Toward the Protected Area of Retezat National Park, Romania. Western Michigan University, Kalamazoo.

Team RC, 2014. R: a language and environment for statistical computing. Vienna, Austria.

Thapa Karki, S., 2013. Do protected areas and conservation incentives contribute to sustainable livelihoods? A case study of Bardia National Park, Nepal. J. Environ. Manage. 128, 988-999. doi:10.1016/j.jenvman.2013.06.054

Tran, L.T., Knight, C.G., O’Neill, R. V, Smith, E.R., O’Connell, M., 2003. Self-organizing maps for integrated environmental assessment of the Mid-Atlantic region. Environ. Manage. 31, 822-35.

Tudor, C.A., Iojă, I.C., Pătru-Stupariu, I., Nită, M.R., Hersperger, A.M., 2014. How successful is the resolution of land-use conflicts? A comparison of cases from Switzerland and Romania. Appl. Geogr. 47, 125-136. doi:10.1016/j.apgeog.2013.12.008

Tudor, C.A., Iojă, I.C., Rozylowicz, L., Pătru-Stupariu, I., Hersperger, A.M., 2015. Similarities and differences in the assessment of land-use associations by local people and experts. Land use policy. doi:10.1016/j.landusepol.2015.07.001

Unnerstall, H., 2008. Public Participation in the Establishment and Management of the Natura 2000 Network: Legal Framework and Administrative Practices in Selected Member States.

Wesselink, A., Paavola, J., Fritsch, O., Renn, O., 2011. Rationales for Public Participation in Environmental Policy and Governance: Practitioners' Perspectives. Environ. Plan. A 43, 2688 2704. doi:10.1068/a44161

Whitehead, A.L., Kujala, H., Ives, C.D., Gordon, A., Lentini, P.E., Wintle, B.A., Nicholson, E., Raymond, C.M., 2014. Integrating biological and social values when prioritizing places for biodiversity conservation. Conserv. Biol. 28, 992-1003. doi:10.1111/cobi.12257

Yorek, N., Ugulu, I., Aydin, H., 2016. Using Self-Organizing Neural Network Map Combined with Ward's Clustering Algorithm for Visualization of Students' Cognitive Structural Models about Aliveness Concept. Comput. Intell. Neurosci. 2016, 1-14. doi:10.1155/2016/2476256

Young, J.C., Watt, A., Jordan, A., Simmons, P., 2015. Conservation conflicts in Natura 2000 protected areas, in: Redpath, S.M., Gutiérrez, R.J., Wood, K.A., Young, J.C. (Eds.), Conflicts in Conservation: Navigating Towards Solutions. Cambridge University Press.

Zhang, L., Scholz, M., Mustafa, A., Harrington, R., 2008. Assessment of the nutrient removal performance in integrated constructed wetlands with the self-organizing map. Water Res. 42, 35193527. doi:10.1016/j.watres.2008.04.027 


\section{APPENDIX A}

Table A.1: Clusters with topics from the consultation reports of the ministry of environmental protection

\begin{tabular}{ll} 
Renamed clusters & $\begin{array}{l}\text { Original cluster labels in the } \\
\text { Romanian language (stem words) }\end{array}$ \\
\hline conservation/activities & indic/activităț \\
information/elements & informaț/element \\
reserves/biotic & rezervaț/biotic \\
surfaces/replace & suprafaț/înlocu \\
order/subchapter & ordonanț/subcapitol \\
actions/agreement & acțiun/acord \\
bold/use & bold/folos \\
hunting/parks & vânat/parc \\
\hline
\end{tabular}

Table A.2: Clusters with topics from the consultation reports of the ministry of agriculture

\begin{tabular}{ll} 
Renamed clusters & $\begin{array}{l}\text { Original cluster labels in the } \\
\text { Romanian language (stem words) }\end{array}$ \\
\hline pastures/sowing & pajișt/însămânțăr \\
grazing/pastures & pășun/pajișt \\
meadow/activities & pajișt/activ \\
reserves/update & rezervaț/complet \\
pastures/mowing & altitud/dat \\
water/fertilizers & apă/prevăz \\
keep/wood & mențin/vegetaț \\
remove/activities & elimin/mențin \\
grazing/activities & pășun/activităț \\
habitat/forest & habit/stăr \\
\hline
\end{tabular}

Table A.3: Clusters with topics from the consultation reports of the ministry of spatial planning

\begin{tabular}{ll} 
Renamed clusters & $\begin{array}{l}\text { Original cluster labels in the } \\
\text { Romanian language (stem words) }\end{array}$ \\
\hline reserves/spatial documents & rezervaț/aprobăr \\
SCIs/spatial documents & comunit/importanț \\
appendices/names & anex/climat \\
authorities/public & administr/public \\
plans/ATUs & dezvolt/administr \\
allow/constructions & art/construcț \\
zoning/rewording & zon/formul \\
\hline SCIs - sites of community interest & \\
ATUs - administrative territorial units &
\end{tabular}

TableA. 4: Clusters with topics from the consultation reports of the ministry of security

\begin{tabular}{ll} 
Renamed clusters & $\begin{array}{l}\text { Original cluster labels in the } \\
\text { Romanian language (stem words) }\end{array}$ \\
\hline security/ attributions & constatăr/paz
\end{tabular}


dogs/vaccination convention/custody unsuitable/terms disaster/intervention institution/prefect dovez/vaccinăr

convent/invoc

abiot/aduc

autor/intervent

institut/prefect

TableA. 5: Clusters with topics from the consultation reports of all four ministries

\begin{tabular}{ll} 
Renamed clusters & $\begin{array}{l}\text { Original cluster labels in the } \\
\text { Romanian language (stem words) }\end{array}$ \\
\hline grazing/pastures & pășun/pajișt \\
pastures/grazing & pajișt/păşun \\
habitat/forest & habit/sens \\
pastures/wood & pajișt/vegetaț \\
meadow/keep & pajișt/mențin \\
grazing/plants & pășun/plant \\
pastures/wild & pajișt/sălbat \\
pastures/requirements & pajișt/cerinț \\
pastures/grazing & pajișt/pășun \\
landowner/payments & termen/plăț \\
forest/landowner & forestier/proprietar \\
land/restrictions, reassess/chapter & funciar/reanaliz \\
urban/plan & urbanist/amenaj \\
institutions/public & instituț/public \\
ordinance/provisions & ordonanț/urgenț \\
\hline
\end{tabular}

